\title{
Islamic Defending Action And Fatwa Defenders Movement Indonesian Ulema Council
}

\author{
Fuad Muhsin ${ }^{1}$, Hani Hanifah², Muhammad Hasan Al As Ari ${ }^{3}$ \\ ${ }^{1}$ Sekolah Tinggi Agama Islam Tasikmalaya \\ ${ }^{2}$ STAIDA Muhammadiyah Garut \\ ${ }^{3}$ STAINU Tasikmalaya \\ Corresponding author E-mail : Fuadmuhsin1987@gmail.com
}

\begin{abstract}
The purpose of this study is to photograph the background of the birth of the National Movement for Defending Fatwa (GNPF) MUI and the methods used by the GNPF activist figures. By using social movement analysis and qualitative methods, this study successfully concluded that the GNPF-MUI and ABI are a consequence of the events and movements of group movements that occurred within the MUI, especially after the New Order. The existence of GNPF and ABI stems from the accommodating Islamistpuritan-conservative groups and tends to be revolutionary in the management of the 2015-2020 MUI. The strategy used by the GNPF actors was carried out by asking for support from revolutionary groups such as FPI to mobilize the period so that their actions receive sociological legitimacy from the Indonesian Muslim community.
\end{abstract}

Keywords: Social Movement, MUI, GNPF and ABI

\section{INTRODUCTION}

Religious populism is a very interesting subject recently discussed about the political movement in Indonesia (Putra, 2019). This is inseparable from the series of historical demonstrations of "Bela Islam" led by the GNPF-MUI (National Movement to Guard Fatwa of the Indonesian Ulema Council) at the end of 2016 and early 2017 in Jakarta which succeeded in gathering the power of Muslims to protest against blasphemy against religion. Ahok (Basuki Tjahaja Purnama). The organization and movement of the GNPF-MUI began with the efforts of Dian Dwi Jayanto 3 to emphasize that the MUI fatwa stating that Basuki Tjahaja Purnama (Ahok), the Governor of Jakarta and the incumbent candidate in the next contestation, had carried out defamation of the Koran (Jayanto, 2019)

MUI can be understood as an organization gathering Muslim clerics and scholars. MUI was established to accommodate all the problems of Muslims and become facilitators of communication between Muslims and the government, therefore the management of MUI tends to be more heterogeneous consisting of representatives of existing Islamic mass organizations such as NU, Muhammadiyah, etc. The role of the ulama in its movement in the archipelago looks very extraordinary, for example in the 18th century, there was an effort to renew and revitalize the teachings of Islam played by the scholars. (Azra, 1998) The scholars also have an important role in the process of religious intellectual transmission from the Islamic scientific center of Makah and Madinah to the Archipelago. The social role of the ulema can still be felt to this day. Especially today the role of the ulema has been institutionalized through MUI institutions.

\footnotetext{
* Copyright (c) 2020 Fuad Muhsin et.all

This work is licensed under a Creative Commons Attribution-ShareAlike 4.0 International License.
} 
International Journal of Islamic Khazanah, Vol. 10 No. 1: 11-15

Islamic Defending Action And Fatwa Defenders Movement Indonesian Ulema Council

Fuad Muhsin, Hani Hanifah, Muhammad Hasan Al Ari

From the beginning of its establishment until approaching the reformation, MUI, both in thought and movement, adequately portrays moderate Islamic groups that are able to accommodate various kinds of Islamic groups, either conservative, traditionalist, progressive, to fundamentalist Islam. However, along with the changing pattern of power from the new order to the reform order, changes were found both structural and cultural changes in the internal MUI. This can be understood because since the era of MUI management reforms began to accommodate a lot of pundamentalist Islamic groups such as LDII, MIUMI, FPI etc.

At the end of 2016, the Indonesian people were shocked by the Indonesian Ulema Council Fatwa Defenders National Movement. This movement is suspected of being initiated by internal administrators of the MUI who have fundamentalist orientation. This can be seen for example from the GNPF activator. The National Movement for Defending Fatwa of the Indonesian Ulema Council was born as a reaction to blasphemy by the former governor of DKI Jakarta. This movement can be understood as a social movement that represents disillusionment with behavior that is deemed to have deviated and crossed traditional boundaries that apply to the community (Abdullah, 2018).

Social movements can be understood as collective efforts to pursue common interests or movements to achieve common goals or joint movements through collective action outside the scope of established institutions (Fadhilah Putra, 2006) According to Denny JA, there are three conditions that can gave birth to social movements namely: first, social movements are born with conditions that provide opportunities for the movement. Moderate government, for example, will provide more opportunities to give birth to social movements than authoritarian governments. Second, social movements arise from dissatisfaction with the existing situation, for example the change from traditional society to modern society. Third, social movements are merely a matter of the ability of leading figures / actors. It is the leader who will network and motivate the community to get involved in the social movement (Fauzi Noor, 2015).

Research on the National Movement for Defending Fatwa (GNPF) and Action in Defending Islam (ABI) has been widely studied by other researchers. including research conducted by Ahmad Najib Burhani with the title Action of Defending Islam: Conservatism and Pragmentation of Religious Authorities (Burhani, 2016). In that study he questioned whether the Islamic Defending Action aimed at religious segmentation in Indonesia. Then there was also a study conducted by Dian Dwi Jayanto with the title Considering the Population of Islamic Population in Indonesia in the Perspective of Discursive Fighting: Contestation of Political Discourse Between the National Movement of Fatwa Guards and Nahdlatul Cleric. In this study he submitted a thesis that the GNPF MUI was not a single force in representing the political aspirations of Muslims in Indonesia (Jayanto, 2019). Here the author takes the viewpoint of the social movement that occurs.

From the explanation above, it is interesting to study the emergence of religious movements that originate from the internal management of the MUI which is allegedly initiated by fundamentalist-oriented clerics..

\section{METHODOLOGY}

The method used in this research is to use a literature study, with a descriptive-analytical approach with the aim to describe the social movement of the Indonesian Ulema Majlis in the context of the Islamic Defending Action (ABI) and the Fatwa Defenders National Movement (GNPF). Data sources are taken from various scientific works such as books and journal articles (Sugiyono, 2010). 
International Journal of Islamic Khazanah, Vol. 10 No. 1: 11-15

Islamic Defending Action And Fatwa Defenders Movement Indonesian Ulema Council

Fuad Muhsin, Hani Hanifah, Muhammad Hasan Al Ari

\section{RESULTS AND DISCUSSION}

The National Movement for Defending Fatwa that led to the Islamic Action, emerged initially as a response to the blasphemy event carried out by the former governor of DKI Jakarta. Action Defending Islam I, II, and III began with a demand that Basuki Tjahaya Purnama (Ahok) be given legal sanctions because he was considered to have blasphemed religion in one of his speeches in the Thousand Islands on September 27, 2016. In the speech Ahok was essentially talking about policy and grouper cultivation empowerment programs. He assured the Thousand Islands residents that this program would continue even though he was not elected again to be the top leader of DKI Jakarta in the February 2017 elections (Burhani, 2016) but there were other things that helped encourage the movement to be born outside the event. First, the change of power configuration from the new regime which tends to be authoritarian to a more democratic reform regime has contributed to the birth of religious-based social movements in Indonesia. Second, economic injustice, income distribution, and the political situation that is not conducive, is one of the reasons for people to be involved in actions that demand structural reforms that lead to the prosecution of the dismissal of the former Jakarta governor from his position. Third, the existence of several actors / figures driving social issues which in this case are MUI officials who collaborate with hardline Islamic movements and several other Islamic groups have helped smooth the social movement which led to the mobilization of the Islamic period.

This 212 action found political momentum when the person accused of blasphemy became one of the candidates for governor in the political contestation (Prayogi, 2019), so that this event could be used as a strategy to win the election by cornering the opposing party in public discourse. Since Ahok replaced Jokowi's position as the governor of DKI, FPI had already carried out a resistance movement against Ahok's leadership, and Ahok had planned to dissolve the organization of Amamar Maruf Nahah Al Munkar. FPI resistance to Ahok broke out after the incident on the island of a thousand with accusations of "blasphemy of religion" and this is the forerunner of the series of Islamic defense movements. The sentiment of nonMuslim and anti-Chinese anti-sentiment became a powerful weapon that rained down on the chaos of the DKI regional election at that time (Ichwan, 2016)

In a social situation like this, then later the MUI as the holder of Islamic religious authority gave a reaction and comment. The MUI's religious opinions and attitudes known as fatwas cannot be detained anymore for issuance. The fatwa stated that Ahok had committed religious defamation and insulted ulemas and Muslims. With the issuance of the fatwa, the feud of Ahok-Rizieq (FPI) seemed to become a dispute of religion (Christianity vs. Islam) and ethnicity (indigenous Chinese) and even the issue of communist ideology had become a topic of discussion in the incident. Therefore, this fatwa succeeded in mobilizing millions of Muslims to demand that Ahok be tried.

In this case, just to see the position of the MUI, the MUI has supported Islamism and the Islamism movement in Indonesia. When referring to the theory of social movements Deny JA which states that social movements are very likely born from the strength of the driving figures. If we analyze the ABI movement, then the main driving actors are not the MUI, but the people of Islamists, but they play the MUI fatwa to legitimize their actions (based on the MUI fatwa). The Islamists proclaimed the movement as a national movement guiding fatwa (GNPF) MUI. So that the GNPF and MUI find a synergy that is symbiotic mutualism in this regard.

During the new order period, the MUI movement as seen in its fatwa product, was more moderate. This is due to the MUI board members from many moderate groups, sometimes conservative and 
International Journal of Islamic Khazanah, Vol. 10 No. 1: 11-15

Islamic Defending Action And Fatwa Defenders Movement Indonesian Ulema Council

Fuad Muhsin, Hani Hanifah, Muhammad Hasan Al Ari

puritanical, cross-mass organizations but still dominated by NU and Muhammadiyyah. In the reform era, MUI began to have a lot of contact with Islamic groups, such as HTI, FPI, LDII, KISDI, FUI. In 2005, the Indonesian Ulema Council issued edicts on the prohibition of secularism, pluralism and liberalism

Fundamental changes in the body of the MUI occurred after the 2015 National Conference in the management of the 2015-2020 MUI, including for example MIUMI figures who were very anti-liberal, for example Bachtiar Natsir, LC as the representative of the MUI consideration board, and a number of other MIUMI figures. The inclusion of MIUMI leaders does not mean that they exclude progressive or liberal figures, but they are still codified as the presence of Azyumardi Azra (progressive group) and Abdul Muqsith Gazali (formerly a ZIL coordinator). ABI was dictated by MUI administrators from the MUI hard wing, Namely Bahtiar Nasir who took the FPI high priest. This hard-wing movement has influenced many moderates and even those who tend to have Sufism also involved in ABI. (Hasan At Turabi, 2013) MUI forum forums that invited Islamic organizations and movements formally such as the Ukhuwah Islamiyyah Forum, and the Indonesian Islamic Society, Incidental forums for public hearings with MUI such as hearings urged the establishment of an MUI fatwa on the Ahok case. In addition, there is an external network within the MUI, which is a logical consequence of representative organizations within the MUI such as the NU and Muhammadiyyah networks, networks of Islamic and nationalist political parties, etc.

Social movements emerge through several stages, and usually arise from a critical state, then experience several stages of development that ends at the stage of the disappearance of social movements or social movements that actually transform themselves into an established social institution. According to WE Gettys, social movements generally pass through the following stages:

1. Anxiety stage, this happens as a result of dissatisfaction with the existing system, in the context of the GNPF and ABI this stage is passed as a reaction of concern to the blasphemy of religion committed by the former Jakarta governor who quoted QS al Maidah who in his statement, megajak community not to be lied to by the verses of the Koran.

2. Anger stage, after attention is paid to dissatisfaction with the existing system, then a collectivity begins to develop, this collectivity usually appears to be moved by the agitator or leader. In this case, the activists began to gather the power of the masses by means of maneuvering and collaboration with other groups who have the same ideological ties in this case the maneuver was carried out against a number of puritan, pundamentalist Islamic figures and even some figures who were allegedly quite radical in their movements.

3. The stage of formalization, at this stage a formal arrangement of management has not yet been formed following the hierarchy of the organizational leadership in general. But it has begun to be propagated about the ideology of the movement to participants who have entered into the union community, also introduced to the causes of dissatisfaction, action plans and objects of the movement to be addressed. This action is evidenced by the action plan propagated through channels of agents who have joined to become part of the community even to the networks that are in regional areas which have a strong enough base.

The stage of institutionalization, in this stage will begin to be formed institutions if the movement succeeded in attracting public attention. In this stage, professional leaders are determined to replace the previous harismatic figures. At this stage an institution was formed which was able to realize the ideals of the movement so that the Islamic Defending Action emerged which ended in the demand for the dismissal of the former Jakarta governor from his position. And to this day, debris from the movement still has a strong network that may repeat its history in the future. Both in the form of the same movement or looking 
for other forms that are not the same as the previous movement but are still influenced by the ideology of the same movement and involve actors from the community who have the same directi.

\section{CONCLUSION}

GNPF-MUI and ABI are a consequence of a series of events and group movements that occurred in the MUI, especially after the New Order. The existence of GNPF and ABI stems from the accommodating Islamist-puritan-conservative groups and tends to be hard on the management of the 2015-2020 MUI. Islamism in the body of the Indonesian Ulema Council has occurred since 2005, when it forbade secularism, pluralism and liberalism. During the New Order era, the MUI's attitude was more moderate, and slightly conservative, because its management was still dominated by moderate-progressive people.

The strategy used by the GNPF actors was carried out by asking for support from hard-line groups like FPI. So when Bahtiar Natsir, the activist, took FPI's high priest Habib Rizieq, it could be understood as a collaboration of forces to mobilize the period so that their action would obtain sociological legitimacy from the Indonesian Muslim community.

This research still needs further research, especially to cover the lack of data surrounding the intellectual actors involved in the social movement in addition, various documentation about the action activities is needed to ensure the accuracy of the information presented.

\section{REFERENCES}

Abdullah, A. (2018). Membaca Komunikasi Politik Gerakan Aksi Bela Islam 212: Antara Politik Identitas dan Ijtihad Politik Alternatif. An-Nida', 41(2), 202-212.

Azra, A. (1998). jaringan Ulama Timur Tengah dan Nusantara abad XVII dan XVIII.

Burhani, A. N. (2016). Aksi Bela Islam: Konservatisme dan Fragmentasi Otoritas Keagamaan. Jurnal Maarif Institute, 2, 15-29.

Fadhilah Putra, D. (2006). Gerakan Sosial, Konsep, Strategi, Aktor, hambatan dan Tantangan Gerakan Soaial di Indonesia. malang: PlaCID's dan Averroes Press.

Fauzi Noor. (2015). Memahami Gerakan-Gerakan Rakyat Dunia ketiga. Yogyakarta: insist Press.

Hasan At Turabi. (2013). al islam wa al hukm. london: As Saqi.

Ichwan, M. N. (2016). MUI, Gerakan Islamis, dan Umat Mengambang. Ma'arif Institute, 87-104.

Jayanto, D. D. (2019). Mempertimbangkan Fenomena Populisme Islam di Indonesia dalam Perspektif Pertarungan Diskursif: Kontestasi Wacana Politik Antara Gerakan Nasional Pengawal Fatwa Ulama (GNPF-Ulama) dan Nahdlatul Ulama (NU). Jurnal Filsafat, 29(1), 125.

Putra, A. E. (2019). Populisme Islam: Tantangan atau Ancaman bagi Indonesia?. Jurnal TAPIs Vol, 15(02), 218.

Prayogi, I. (2019). Populisme Islam dan Imajinasi Politik dalam Pilkada DKI Jakarta 2017. Politeia: Jurnal Ilmu Politik, 11(2), 31-43.

Sugiyono, D. (2010). Metode penelitian kuantitatif dan R\&D. Bandung: Alfabeta. 